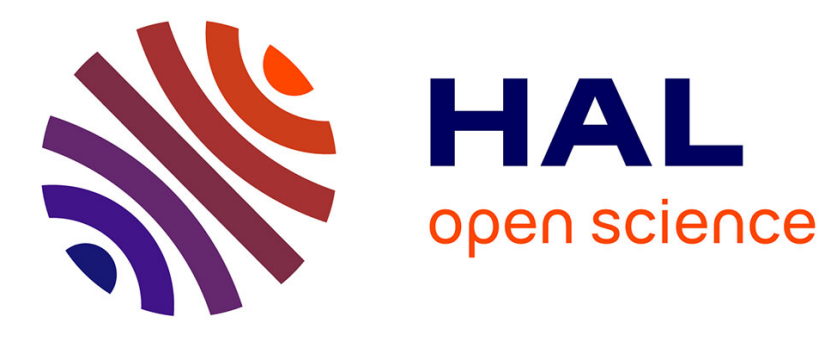

\title{
Macrocyclic Hamilton-type Receptors Comprising a Ferrocene Pivot
}

\author{
Luca Pisciottani, Maxime Douarre, Brigitte Bibal, Clotilde Davies, Holly \\ Roberts, Brice Kauffmann, Sarah S Horswell, James H R Tucker, Nathan \\ Mcclenaghan
}

\section{To cite this version:}

Luca Pisciottani, Maxime Douarre, Brigitte Bibal, Clotilde Davies, Holly Roberts, et al.. Macrocyclic Hamilton-type Receptors Comprising a Ferrocene Pivot. Supramolecular Chemistry, 2018, 10.1080/10610278.2018.1426856 . hal-02337898

\section{HAL Id: hal-02337898 \\ https://hal.science/hal-02337898}

Submitted on 29 Oct 2019

HAL is a multi-disciplinary open access archive for the deposit and dissemination of scientific research documents, whether they are published or not. The documents may come from teaching and research institutions in France or abroad, or from public or private research centers.
L'archive ouverte pluridisciplinaire HAL, est destinée au dépôt et à la diffusion de documents scientifiques de niveau recherche, publiés ou non, émanant des établissements d'enseignement et de recherche français ou étrangers, des laboratoires publics ou privés. 


\section{Macrocyclic Hamilton-type Receptors Comprising a Ferrocene Pivot}

Luca Pisciottani $^{\mathrm{a} \S}$, Maxime Douarre ${ }^{\mathrm{a} \S}$, Brigitte Bibal $^{\mathrm{a}}$, Clotilde Davies ${ }^{\mathrm{a}}$, Holly Roberts ${ }^{\mathrm{b}}$, Brice Kauffmann ${ }^{\mathrm{c}}$, Sarah L. Horswell, James H. R.

Tucker $^{\text {b* }}$ and Nathan D. McClenaghan ${ }^{\mathrm{a} *}$

${ }^{a}$ Institut des Sciences Moléculaires, CNRS UMR 5255, University of Bordeaux, 33405 Talence, France

E-mail: nathan.mcclenaghan@u-bordeaux.fr

${ }^{b}$ School of Chemistry, University of Birmingham, Edgbaston, B15 2TT Birmingham, United Kingdom

E-mail: J.Tucker@bham.ac.uk

${ }^{c}$ Institut Europeen de Chimie et Biologie, CNRS UMS 3033, University of Bordeaux, 33607 Pessac, France

$\S$ These authors contributed equally to this work. 


\title{
Macrocyclic Hamilton-type Receptors Comprising a Ferrocene Pivot
}

\author{
Synthetic hydrogen-bonding receptors are described, which incorporate a central \\ electroactive ferrocene moiety grafted with two adjacent bis(amido)pyridine \\ motifs and an aliphatic tether (14 and 18 methylene units for $\mathbf{1}$ and $\mathbf{2}$, \\ respectively) completing the macrocycle. The crystallographic structure, \\ barbiturate guest-binding studies and electrochemical data are provided for the \\ more strongly-binding macrocycle 2 .
}

Keywords: Macrocycle, ferrocene, Hamilton receptor, hydrogen-bonding, barbiturate

\section{Introduction}

Among a wealth of known selective synthetic hydrogen-bonding receptors, the molecular recognition motif described by Hamilton and coworkers (1-3) has earned a privileged place. This motif draws upon six complementary hydrogen bonds, affording a donor (D)-acceptor(A) DADDAD:ADAADA pattern (referring to the receptor and guest, respectively) to exclusively form 1:1 complexes with an appropriate guest molecule (such as barbiturates) with a high binding constant in non-competitive solvents $\left(K_{\text {ass }}=10^{4}-10^{5} \mathrm{M}^{-1}\right)$. A diversity of hydrogen-bonding supramolecular constructs have been described which harness Hamilton-like receptors and complementary guests, including dendrimers and supramolecular polymers, as described in a recent review (4) of H-bonding supramolecular architectures incorporating variants of this versatile receptor. Macrocyclic versions are known to typically afford higher guest affinities and we recently described their use in forming pseudorotaxane architectures and their subsequent covalent capture giving rotaxanes via mild Huisgen and Glaser coupling reactions $(5,6)$, as well as photochemical rotaxanetrapping from acyclic components (7). As part of our ongoing interest in redox-active supramolecular systems $(8,9)$, and in particular the development of H-bonding receptors 
for organic molecules (9), herein we describe the synthesis, structural considerations and binding properties of novel electroactive macrocyclic Hamilton-like receptors of different size (1 and 2), which incorporate a central ferrocene motif in place of a phenyl group. The macrocycle design builds on a previously reported acyclic tetra-amide version (10), whose crystal structure is shown in Figure 1a, and, when the two $\mathrm{HNC}(\mathrm{O})$ Et groups are rather $-\mathrm{NH}_{2}$ (molecule 4 in this work), serves as a synthetic intermediate for the preparation of $\mathbf{1}$ and $\mathbf{2}$. The macrocyclic variants (Figure $1 \mathrm{~b}$ ) aimed to improve the binding properties for a guest barbiturate moiety with respect to the receptor shown in Figure 1a due to the structural integrity of the macrocycle, due to paying entropic costs and which in turn were anticipated to tune the redox properties of the ferrocene centre. Figure 1c shows the structural formula of barbital guest $\mathbf{3}$, while Figure 1d shows a single crystal X-ray structure of a related host-guest supramolecular adduct (lacking the electroactive ferrocene) and possibilities for multiple H-bonding of guest $3(5)$.

a)

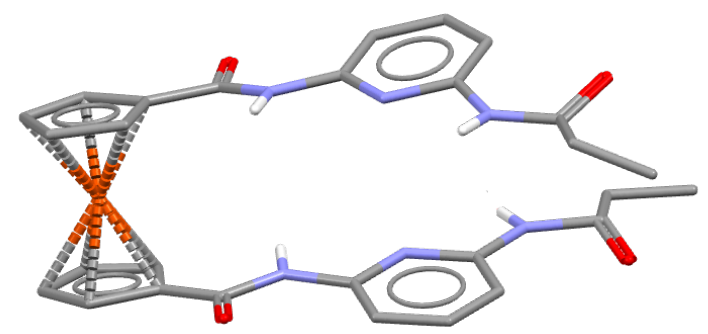

b)

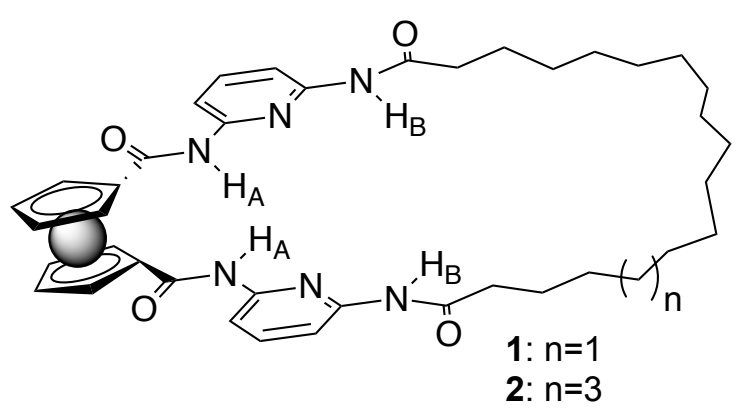


c)<smiles>CCC1(CC)C(=O)NC(=O)NC1=O</smiles>

d)

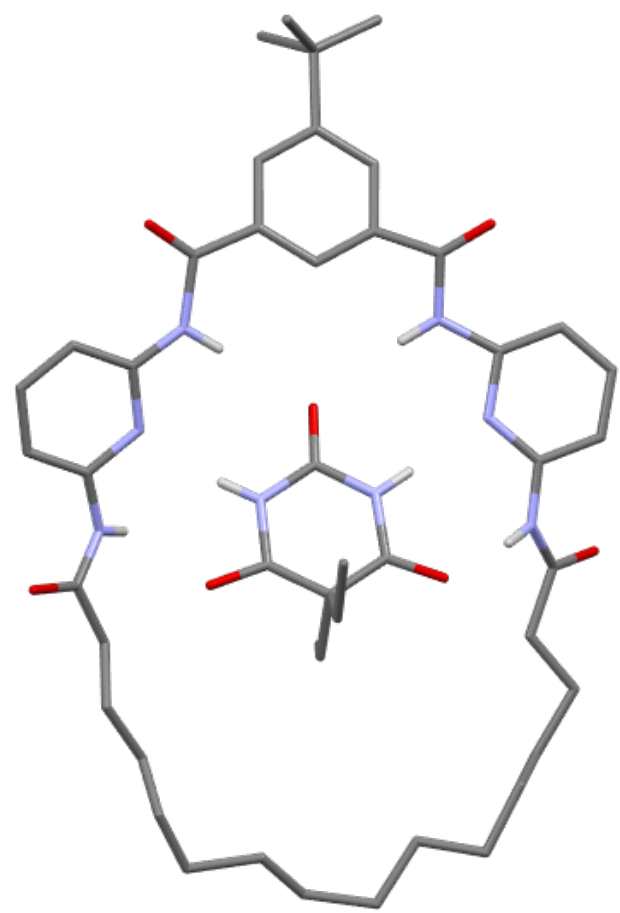

Figure 1. a) Single crystal X-ray structure of acyclic Hamilton-like ferrocenecontaining receptor (10). b) Structural formulae of macrocyclic receptors 1 and $2 . \mathrm{H}_{\mathrm{A}}$ and $\mathrm{H}_{\mathrm{B}}$ denote protons used to follow guest binding in NMR studies (vide infra). c) Single crystal X-ray structure of macrocyclic Hamilton-type receptor with guest 3.

\section{Results and discussion}

The macrocyclic receptors $\mathbf{1}$ and $\mathbf{2}$ were synthesized as shown in Scheme 1, through a one-pot double condensation between both terminal $-\mathrm{NH}_{2}$ groups of acyclic 4 with the appropriate aliphatic $\alpha, \omega$-diacid chloride. Molecule 4 was synthesized as reported in the literature (11), but we note in passing that higher quality intermediates, namely the 1,1 'ferrocene dicarboxylic acid and the corresponding acid chloride, could be obtained by recrystallization in acetic acid and heptane, respectively. 


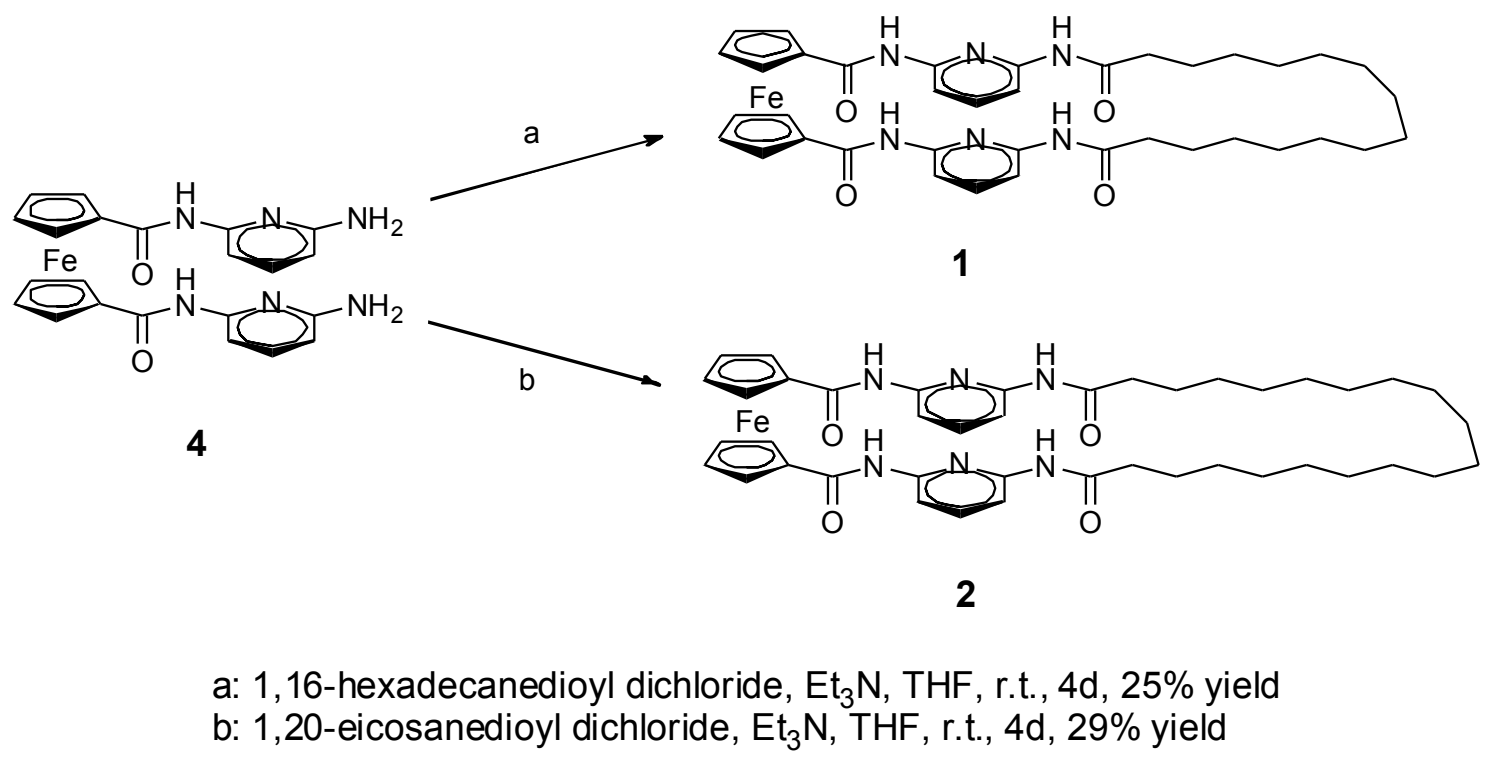

Scheme 1. Synthesis of 1 and 2.

Single crystals of suitable quality for X-ray structural determination were obtained for 2, whose structure is shown in Figure 2. Crystals were grown by vapor diffusion of diethyl ether into a concentrated acetic acid solution of $\mathbf{2}$ at room temperature, while high quality crystals of $\mathbf{1}$ proved elusive.

The crystal structure of $\mathbf{2}$ shows that each molecule forms one $\mathrm{NH} \cdot \cdot \mathrm{O}=\mathrm{C}$ hydrogen bond to an adjacent molecule (Figure 2b). The ferrocene units adopt an orthogonal stacked architecture that presumably helps to accommodate these bulky units within the supramolecular structure. Bilayers are formed, the bulky electron-rich ferrocene units facing each other. The crystal packing of molecules is mostly driven by van der Waals interactions, so that all available void space is filled with the cyclic aromatic chains $\left(60^{\circ}\right.$ angle between planes defined by aliphatic chains of 2 adjacent molecules). 
a)

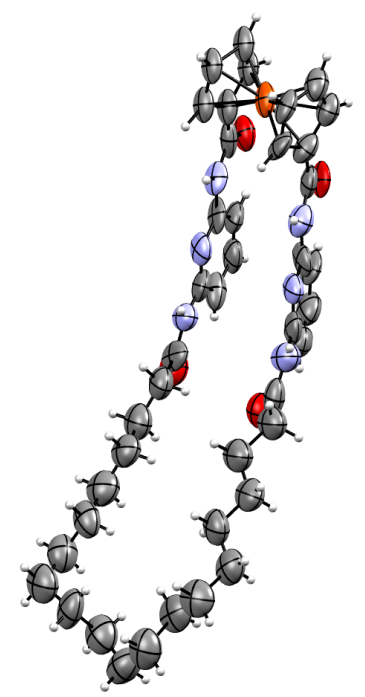

b)

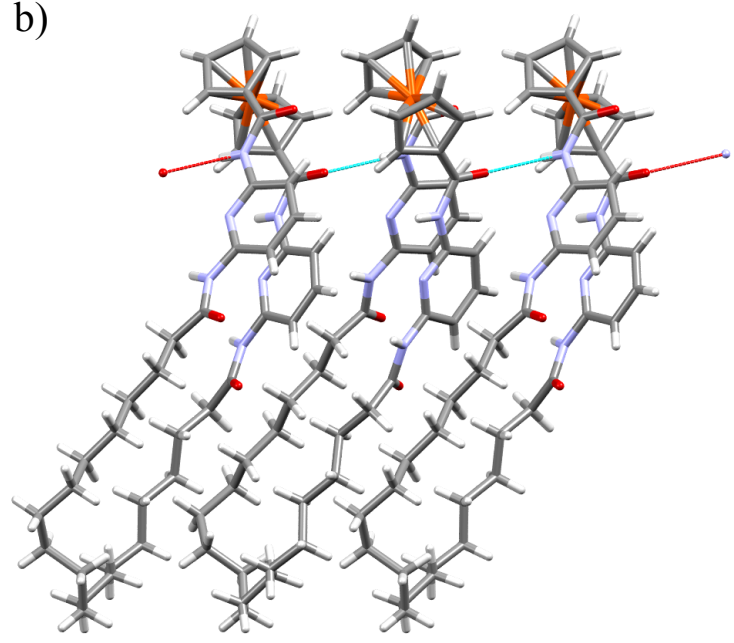

Figure 2. (a) Ortep view of molecule 2. Ellipsoids displayed at 50\% probability. (b) Hydrogen bonding network in the crystal structure of 2. Cambridge crystal database code: CCDC 1568518.

The interactions of macrocycles $\mathbf{1}$ and $\mathbf{2}$ with barbiturate $\mathbf{3}$ were studied by UVvisible and ${ }^{1} \mathrm{H}$ NMR spectroscopies in chlorinated solvents at $293 \mathrm{~K}$.

From the electronic absorption spectra, the formation of host:guest complexes was denoted by a small red-shift of some nanometres of the pyridine absorption band (Figure 3a). An isosbestic point was observed at ca. $310 \mathrm{~nm}$ for both titrations of 1 and 2 with 3 . The data were analysed by the Letagrop program $(12,13)$ and provided $(1: 1)$ binding constants of $727 \pm 1 \mathrm{M}^{-1}$ for $\mathbf{1}$ and $1032 \pm 1 \mathrm{M}^{-1}$ for $\mathbf{2}$ in dichloromethane.

The titrations monitored by ${ }^{1} \mathrm{H}$ NMR $\left(\mathrm{CDCl}_{3}\right)$ revealed that the signals for both $\mathrm{NH}$ groups of the different amide groups in $\mathbf{1}$ and $\mathbf{2}$ are shifted downfield upon addition of increasing amounts of $\mathbf{3}$ (Figure $3 \mathrm{~b}$ ). This observation is consistent with the expected formation of hydrogen bonds between host and guest. We tentatively ascribe the $\mathrm{N}-\mathrm{H}_{\mathrm{A}}$ (see figure $1 \mathrm{~b}$ for labels) as being the more shielded protons, with respect to $\mathrm{N}-\mathrm{H}_{\mathrm{B}}$, 
being adjacent to the electron-rich ferrocene. The analysis of the binding isotherm allowed the determination of (host:guest; 1:1) binding constants of $c a .10^{3} \mathrm{M}^{-1}: 742 \pm$ $10 \mathrm{M}^{-1}$ for 1 and $1011 \pm 8 \mathrm{M}^{-1}$ for 2 , respectively (14). Thus binding constants of the ferrocene-containing macrocycles with 3 determined by both UV-visible and NMR monitoring proved to be consistent.

a)

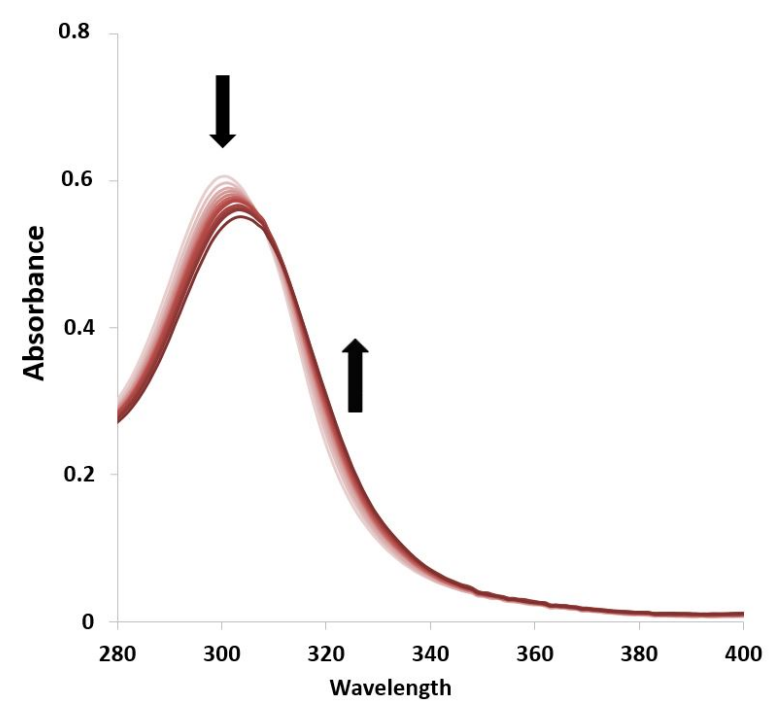

b)

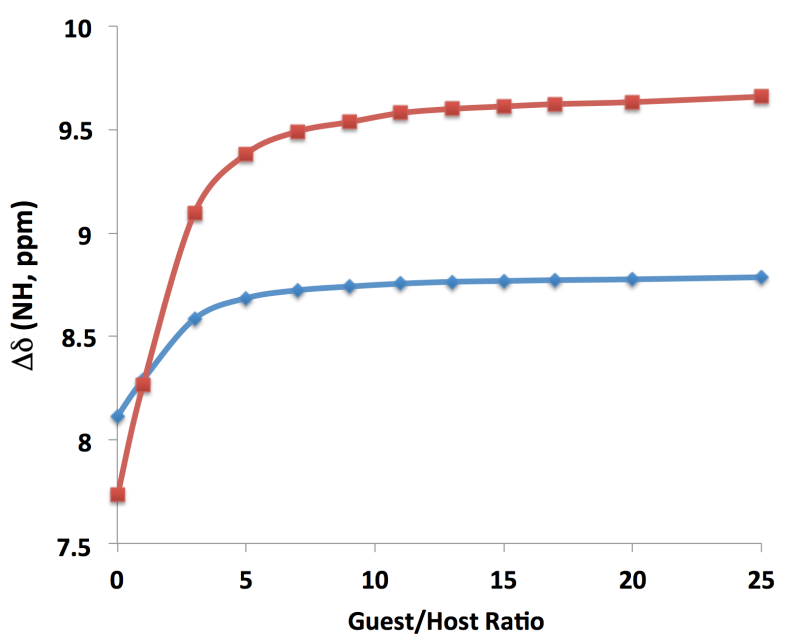

Figure 3. Titration of $\mathbf{1}$ in the presence of guest $\mathbf{3}$ monitored by: a) UV-visible spectroscopy $\left(2.5 \times 10^{-5} \mathrm{M}\right.$ in $\left.\mathrm{CH}_{2} \mathrm{Cl}_{2}\right)$. b) ${ }^{1} \mathrm{H}$ NMR using the chemical shifts of the host amide protons $\left(1 \mathrm{mM}\right.$ in $\left.\mathrm{CDCl}_{3}\right)$. Squares $=\mathrm{N}-\mathrm{H}_{\mathrm{A}}$ protons; Diamonds $=\mathrm{N}-\mathrm{H}_{\mathrm{B}}$ protons (cf. Figure 1b). 
A previously reported acyclic version of the receptor, which consisted of a bisethylamide compound (Figure 1a) gave a slightly lower binding constant with $\mathbf{3}$ of $575 \mathrm{M}^{-1}$ in $\mathrm{CDCl}_{3}(10)$. Macrocycles $\mathbf{1}$ and 2 may be anticipated to offer a more preorganised binding site to bind guest $\mathbf{3}$, which would lower the free energy cost for complexation.

From electrochemical experiments, macrocycle 2 was seen to undergo a redox transition $\left(\mathrm{Fc} / \mathrm{Fc}^{+}\right)$at $E_{1 / 2}=1( \pm 0.005) \mathrm{V}$ vs. decamethyl ferrocene (DCMF) as internal standard, where $E_{1 / 2}=\left(E_{\mathrm{p}}{ }^{\mathrm{a}}+E_{\mathrm{p}}{ }^{\mathrm{c}}\right) / 2$, (Figure 4). For a fully reversible system, the peak separation $\left(\Delta E_{\mathrm{p}}=E_{\mathrm{p}}{ }^{\mathrm{a}}-E_{\mathrm{p}}{ }^{\mathrm{c}}\right)$ would be expected to be close to $59 \mathrm{mV}$ for a one electron process (15). However, for $2, \Delta E_{\mathrm{p}}$ gradually increases with increasing scan rate (Table 1), suggesting quasi-reversible behaviour.

Table 1. Peak separation $\left(\Delta E_{\mathrm{p}}\right)$ values for $\mathbf{2}$ at varying scan rates.

\begin{tabular}{|c|l|l|l|l|l|l|l|l|}
\hline Scan rate / V s-1 & 0.01 & 0.02 & 0.04 & 0.06 & 0.08 & 0.1 & 0.25 & 0.5 \\
\hline$\Delta E_{\mathrm{p}} / \mathrm{mV}$ & 21 & 68 & 68 & 72 & 72 & 77 & 96 & 124 \\
\hline
\end{tabular}

Plots of the square root of the scan rate vs current (Figure 5) gave a linear correlation. Consequently the diffusion coefficient of DCMF and 2 could be determined $(16,17)$ using the Randles- Ševčik equation (Equation 1).

$$
i_{p}=2.69 \times 10^{5} n^{3 / 2} A D^{1 / 2} C v^{1 / 2} \quad \text { Eq. } 1
$$

Where: $i_{\mathrm{p}}=$ peak current $(\mathrm{A}), n=$ no. of electrons transferred per molecule in redox process, $A=$ microscopic electrode surface area $\left(\mathrm{cm}^{2}\right), D=$ diffusion coefficient $\left(\mathrm{cm}^{2} \mathrm{~s}^{-}\right.$ $\left.{ }^{1}\right), C=$ bulk concentration of electrolyte $\left(\mathrm{mol} \mathrm{dm}^{-3}\right), v=$ scan rate $\left(\mathrm{V} \mathrm{s}^{-1}\right)$. 
The resultant diffusion coefficients were $5.7 \times 10^{-9} \mathrm{~cm}^{2} \mathrm{~s}^{-1}$ and $1.5 \times 10^{-9} \mathrm{~cm}^{2} \mathrm{~s}^{-1}$ for DCMF and 2, respectively. The reduced diffusion coefficient of $\mathbf{2}$ compared to DCMF is attributed to the large size of the molecule and the resultant increase in the resistivity of movement through the electrolyte.

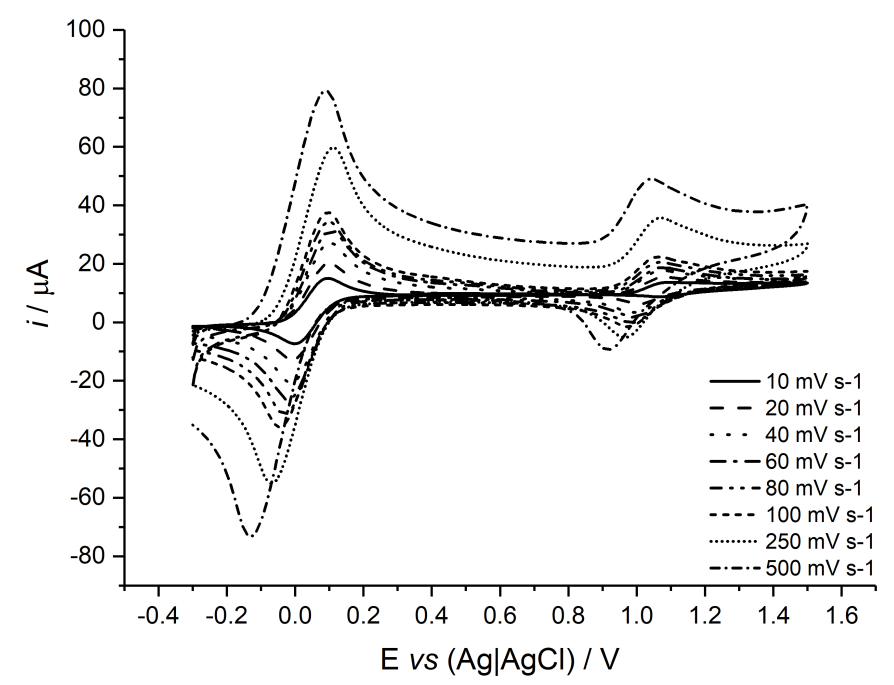

Figure 4. Cyclic voltammograms of 1:1 DCMF and 2, recorded at varying scan rates, in a solution of $0.1 \mathrm{M} \mathrm{TBAPF}_{6}$ in dry $\mathrm{CH}_{2} \mathrm{Cl}_{2}$ with a glassy carbon working electrode, platinum wire counter electrode and silver wire pseudo-reference electrode.

DCMF

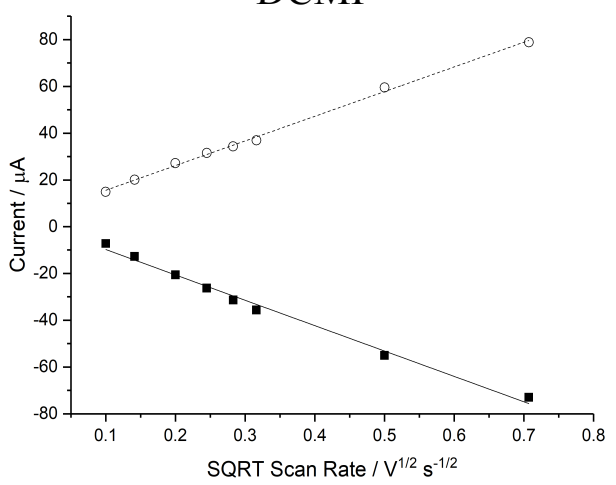

2

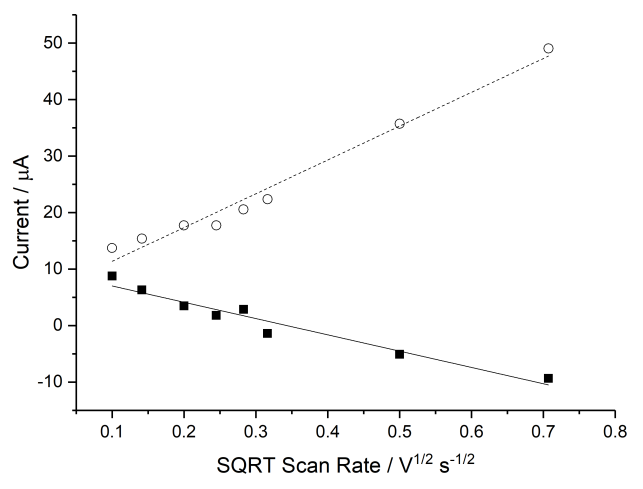


Figure 5. Plots of square root of the scan rate vs. current for DCMF and 2, where white circles and black squares indicate data derived from anodic and cathodic peaks, respectively.

As shown in Figure 6, no substantial change in the electrochemical formal potential vs. DCMF (i.e. $\Delta E_{1 / 2} \leq \pm 5 \mathrm{mV}$ ) was observed upon the addition of barbital (Figure 6), which was in contrast to small negative values that were observed for the previously reported acyclic receptors (10) and for other ferrocene receptors that bind organic guest molecules through H-bonding interactions (9). Nevertheless, it should be noted that the solution changed in appearance from slightly clouded to transparent, typically an indicator for association-aided dissolution. Since the ferrocene-containing receptor site is similar in both previous acyclic and the current cyclic variants, one can tentatively infer that the different electrochemical behaviour is principally due to geometricinfluences on the electronic communication between the ferrocene unit and the $\mathrm{H}$ bonding sites where barbital binding occurs and/or potential interaction between the stacked diamidopyridine moieties in the macrocyclic variant, as revealed by X-ray crystallography. 


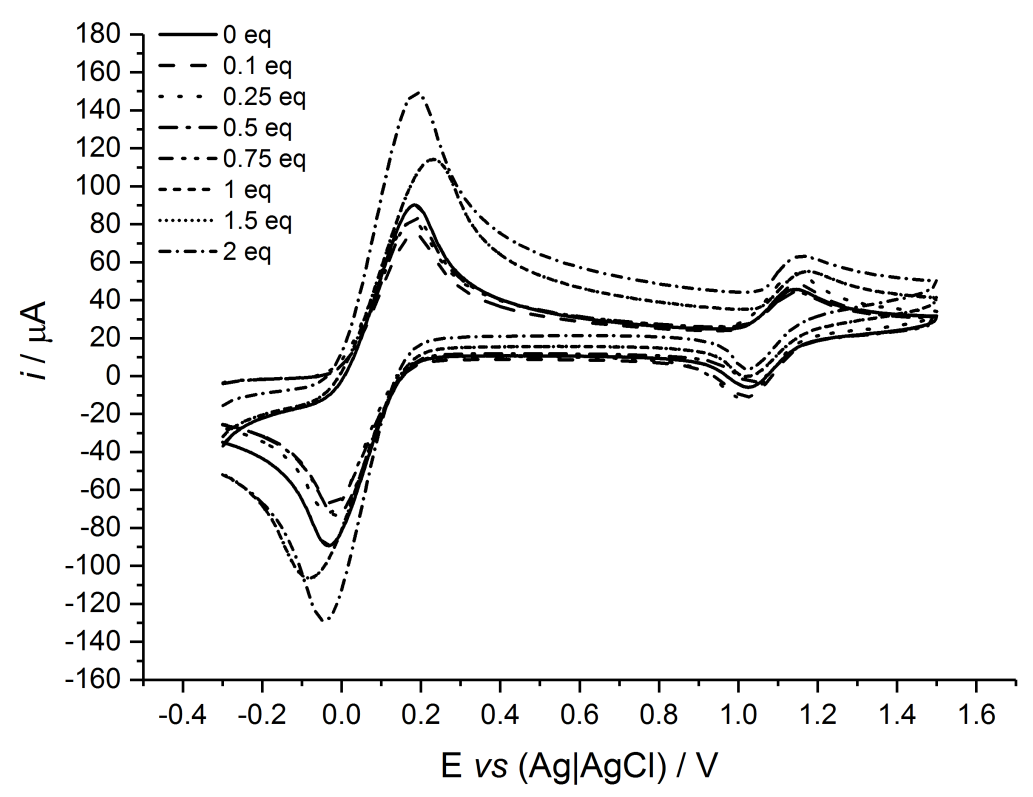

Figure 6. CVs recorded of DCMF and 2 on addition of $0.1-2$ molar equivalents of barbital (3). Scan rate $=500 \mathrm{mV} \mathrm{s}^{-1}$, in $0.1 \mathrm{M} \mathrm{TBAPF}_{6}$ in dry $\mathrm{CH}_{2} \mathrm{Cl}_{2}$.

\section{Conclusion}

Macrocyclic versions of a Hamilton-like receptor incorporating a central ferrocene (1 and 2) have been successfully synthesized. Six potential hydrogen-bonding sites are comprised within these receptors, some of which can be invoked to bind a barbiturate guest, whose binding was investigated via spectrophotometric, NMR and electrochemical experiments. The determined binding constants $\left(K_{\text {ass }}=742 \mathrm{M}^{-1}\right.$ for $\mathbf{1}$ and $K_{\text {ass }}=1011 \mathrm{M}^{-1}$ for $\mathbf{2}$ in $d$-chloroform, respectively) were found to be only slightly higher (10) than the previously reported acyclic version $\left(K_{\mathrm{ass}}=575 \mathrm{M}^{-1}\right.$ in $d$ chloroform), and much lower than recently reported structural analogues where a central tert-butyl phenyl is surrogate (5) for the ferrocene moiety $\left(K_{\mathrm{ass}}=23,500 \mathrm{M}^{-1}\right.$ in chloroform). Crystallographic structural analysis of $\mathbf{2}$ elucidated a crescent-shaped structure and twisting of H-bonding groups out of the plane of the binding cavity, 
making the receptor site ill-adapted to accommodate a barbiturate guest through six strong H-bonds, thereby off-setting the advantage imparted by the macrocyclic nature of the receptor. While the ferrocene is seen to retain its characteristic redox chemistry, titrations followed by cyclic voltammetry show that the influence of the guest has a negligible effect on the formal potential of the redox-active centre. This indicates that the preorganised nature of the receptor framework, when compared with the corresponding acyclic systems, reduces the effect that barbital binding has on the ease of oxidation of the ferrocene centre.

\section{Experimental}

\section{Materials and methods}

Acyclic receptor (4) was synthesized as reported previously (11). All manipulations were performed under a dry argon atmosphere using standard techniques. Commercially-available reagents and solvents (Sigma-Aldrich, Acros and Alfa Aesar) were used as received unless otherwise stated. The progress of all reactions was monitored by thin layer chromatography on silica gel $40 \mathrm{~F}_{254}$. Column chromatography was performed on silica gel $40\left(0.230-0.400 \mathrm{~mm}\right.$ or $40-63 \mu \mathrm{m}$, Sigma-Aldrich). ${ }^{1} \mathrm{H}$ and ${ }^{13} \mathrm{C}-\mathrm{NMR}$ experiments were performed at $295 \mathrm{~K}$ on a Brüker Avance $300\left({ }^{1} \mathrm{H}: 300\right.$ $\left.\mathrm{MHz},{ }^{13} \mathrm{C}: 75 \mathrm{MHz}\right)$ and an Avance III $600\left({ }^{1} \mathrm{H}: 600 \mathrm{MHz},{ }^{13} \mathrm{C}: 150 \mathrm{MHz}\right)$ spectrometer. Chemical shifts are reported in ppm $(\delta)$ and are referenced to the NMR solvent residual peaks. For the assignment of signals, the following abbreviations are used are $\mathrm{s}=$ singlet, $\mathrm{d}=$ doublet, $\mathrm{t}=$ triplet. Mass spectra were performed by the CESAMO (Bordeaux, France) on a QStar Elite mass spectrometer (Applied Biosystems). ESIQTOF mass spectra (including all HRMS) were performed on an instrument equipped with an ESI source and spectra were recorded in the positive mode. The electrospray 
needle was maintained at $5000 \mathrm{~V}$ and operated at room temperature. Samples were introduced by injection through a $20 \mu \mathrm{L}$ sample loop into a $4500 \mu \mathrm{L} / \mathrm{min}$ flow of methanol from the LC pump. ESI-MS experiments were performed on an ion trap spectrometer equipped with an electrospray ion source (ESI). Field desorption (FD) spectra were recorded on a TOF mass spectrometer using an FD emitter with an emitter voltage of $10 \mathrm{kV}$. One to two microliters solution of the compound is deposited on a $13 \mu \mathrm{m}$ emitter wire. Electronic absorption spectra were measured on a Varian Cary 5000 UV-vis-NIR spectrophotometer. Crystallographic data (see SI, Table 1) collection was performed at the IECB X-ray facility (UMS3033) on a high flux microfocus Rigaku FRX rotating anode at the copper $\mathrm{k}_{\alpha}$ wavelength equipped with osmic Varimax mirrors and a Dectris Pilatus $200 \mathrm{~K}$ hybrid detector. The crystal was mounted on a cryo-loop after quick soaking on Paratone- $\mathrm{N}$ oil from Hampton research and flash-frozen. The diffractometer is composed of a partial chi geometry goniometer allowing omega-scan data collections. The data were processed with the CrysAlisPro v38.46. The crystal structure was solved using direct methods implemented in SHELXT and refined using SHELXL 2013 version $(18,19)$. Full-matrix least-squares refinement were performed on $\mathrm{F}^{2}$ for all unique reflections, minimizing $\mathrm{w}\left(\mathrm{Fo}^{2}-\mathrm{Fc}^{2}\right)^{2}$, with anisotropic displacement parameters for non-hydrogen atoms. Hydrogen atoms were positioned in idealized positions and refined with a riding model, with Uiso constrained to 1.2 Ueq value of the parent atom (1.5 Ueq when $\left.\mathrm{CH}_{3}\right)$. The positions and isotropic displacement parameters of the remaining hydrogen atoms were refined freely. RIGU commands were used to restrain some carbon atoms of the aliphatic chain as rigid groups and restrain their displacement parameters. Data statistics are presented in table S1 and in the cif files.

Electrochemical experiments were carried out as follows: a glassy carbon working electrodes was polished in a figure of eight fashion using 1, 0.3 and 0.05 gamma 
alumina on a microcloth pad (Buehler, UK) (for 3.3 and 5 mins respectively). The electrode was then sonicated in 1:1 ethanol/water for 5 mins and washed in stream of dry DCM for 1 min. The counter electrode was a platinum wire, which was cleaned by heat annealing before quenching with dry DCM. A Ag wire was used as a pseudo reference electrode after heat annealing and quenching with dry DCM. Both were used immediately after washing. The supporting electrolyte was a solution of $0.1 \mathrm{M} \mathrm{TBAPF}_{6}$ and $1 \mathrm{mM}$ decamethylferrocene (to act as an internal reference) dissolved in dry DCM and degassed with argon for 15 mins. 2 was dissolved in the electrolyte at a concentration of $1 \mathrm{mg} / \mathrm{mL}$. This solution was subsequently sonicated for 10 mins. All CVs were carried out under argon and an argon flush was continued during the stirring between additions of the relevant compounds (which was carried out in situ).

\section{Synthesis of 1}

To a stirred solution of dry THF (50 mL) under argon, acyclic receptor 4 (456 mg, 1 mmol) and triethylamine $(280 \mu \mathrm{L}, 2 \mathrm{mmol})$ in THF $(100 \mathrm{~mL})$ and 1,16-hexadecanedioyl dichloride (323 mg, $1 \mathrm{mmol})$ in THF (100 mL) were added dropwise simultaneously, over $3 \mathrm{~h}$. The mixture was stirred at room temperature for 4 days, then the solvent and the volatiles were removed under vacuum. The crude product was dissolved in chloroform $(250 \mathrm{~mL})$ and washed with a saturated solution of $\mathrm{Na}_{2} \mathrm{CO}_{3}(2 \times 200 \mathrm{~mL})$ and brine $(200 \mathrm{~mL})$. The organic phase was dried over $\mathrm{MgSO}_{4}$ and the solvent was removed. Purification by column chromatography $\left(\mathrm{SiO}_{2}, \mathrm{MeOH}: \mathrm{DCM}, 1: 49\right.$, v/v) afforded 1 as an orange solid (179 mg, yield: 25\%). ${ }^{1}$ H NMR (600 MHz, Acetic Acid$\mathrm{d} 4): \delta 7.96-7.66(\mathrm{~m}, 6 \mathrm{H}), 5.19-5.16(\mathrm{~m}, 4 \mathrm{H}), 4.70-4.68(\mathrm{~m}, 4 \mathrm{H}), 2.52(\mathrm{t}, J=7.5 \mathrm{~Hz}$ 4H), 1.83 - 1.68 (m, 4H), 1.52 - 1.34 (m, 20H). ${ }^{13}$ C NMR (600 MHz, Acetic Acid - d4): $\delta 174.1,169.2,148.6,148.2,142.6,109.9,76.1,73.3,70.5,36.6,28.4,28.3,28.2,28$, 
27.7, 27.5, 24.6. HRMS (ESI) calcd for $\mathrm{C}_{38} \mathrm{H}_{46} \mathrm{~N}_{6} \mathrm{O}_{4} \mathrm{NaFe}[\mathrm{M}+\mathrm{Na}]^{+} \mathrm{m} / \mathrm{z}=729.2822$, found $\mathrm{m} / \mathrm{z}=729.2836$.

\section{Synthesis of 2}

To a stirred solution of dry THF $(50 \mathrm{~mL})$ under argon, acyclic receptor 4 (456 mg, 1 mmol) and triethylamine $(280 \mu \mathrm{L}, 2 \mathrm{mmol})$ in THF $(100 \mathrm{~mL})$ and 1,20-eicosanedioyl dichloride (379 mg, $1 \mathrm{mmol})$ in THF (100 mL) were added dropwise simultaneously, over $3 \mathrm{~h}$. The mixture was stirred at room temperature for 4 days, then the solvent and the volatiles were removed under vacuum. The crude product was dissolved in chloroform $(250 \mathrm{~mL})$ and washed with a saturated solution of $\mathrm{Na}_{2} \mathrm{CO}_{3}(2 \times 200 \mathrm{~mL})$ and brine $(200 \mathrm{~mL})$. The organic phase was dried over $\mathrm{MgSO}_{4}$ and the solvent was removed. Purification by column chromatography $\left(\mathrm{SiO}_{2}, \mathrm{MeOH}: \mathrm{DCM}, 1: 49, \mathrm{v} / \mathrm{v}\right)$ afforded 2 as an orange solid (225 mg, yield: 29\%). ${ }^{\mathbf{1}} \mathbf{H}$ NMR (600 MHz, Acetic Acidd4): $\delta 7.84-7.68(\mathrm{~m}, 6 \mathrm{H}), 5.17(\mathrm{~s}, 4 \mathrm{H}), 4.69(\mathrm{~s}, 4 \mathrm{H}), 2.52(\mathrm{t}, J=6.8 \mathrm{~Hz}, 4 \mathrm{H}), 1.80-$

$1.70(\mathrm{~m}, 4 \mathrm{H}), 1.48-1.33(\mathrm{~m}, 28 \mathrm{H}) .{ }^{13} \mathrm{C}$ NMR (600 MHz, Acetic Acid - d4): $\delta$ 174.1, $169.1,148.5,148.2,142.6,109.8,76.2,73.1,70.6,36.7,28.8,28.7,28.5,28.3,28.1$, 27.8, 27.7, 24.8. HRMS (ESI) calcd for $\mathrm{C}_{42} \mathrm{H}_{54} \mathrm{~N}_{6} \mathrm{O}_{4} \mathrm{NaFe}[\mathrm{M}+\mathrm{Na}]^{+} \mathrm{m} / \mathrm{z}=785.3448$, found $\mathrm{m} / \mathrm{z}=729.3459$.

\section{Acknowledgements}

Financial support from the Agence Nationale de la Recherche (project ANR-16-CE290011; pre-doctoral bourse M.D), University of Bordeaux; CNRS and Ministère de la Recherche et de l'Enseignement Supérieur (L.P.) is gratefully acknowledged.

\section{References}

(1) Chang, S.-K.; Hamilton, A. D. J. Am. Chem. Soc. 1988, 110, 1318. 
(2) Chang, S.-K.; Van Engen, D.; Fan, E.; Hamilton, A. D. J. Am. Chem. Soc. 1991, 113,7640 .

(3) Geib, S. J.; Vivent, C.; Fan, E.; Hamilton, A. D. Angew. Chem., Int. Engl. 1993, 32, 119.

(4) Tron, A.; Rocher, M.; Thornton, P.J.; Tucker, J.H.R.; McClenaghan, N. D. Asian J. Org. Chem., 2015, 4, 192.

(5) Tron, A.; Thornton, P. J.; Rocher, M.; Jacquot de Rouville, H.-P.; Desvergne, J.-P.; Kauffmann, B.; Buffeteau, T.; Cavagnat, D.; Tucker, J. H. R.; McClenaghan, N. D. Org. Lett. 2014, 16, 1358.

(6) Tron, A.; Thornton, P.; Kauffmann, B.; Tucker, J.H.R.; McClenaghan, N. D. Supramol. Chem., 2016, 28, 733.

(7) Tron, A.; Thornton, P. J.; Lincheneau, C.; Desvergne, J.-P.; Spencer, N.; Tucker, J. H. R.; McClenaghan, N. D. J. Org. Chem. 2015, 80, 988.

(8) Duprey, J.-L. H. A.; Carr-Smith, J.; Horswell, S. L.; Kowalski, J.; Tucker, J. H. R., J. Am. Chem. Soc., 2016, 138, 746.

(9) Mulas, A.; Willener, Y.; Carr-Smith, J.; Joly, K. M.; Male, L.; Moody, C. J.; Horswell, S. L.; Nguyen, H. V.; Tucker, J. H. R.; Dalton Trans., 2015, 44, 7268 and references cited therein.

(10) Westwood, J.; Coles, S. J.; Collinson, S. R.; Gasser, G.; Green, S. J.; Hursthouse, M. B.; Light, M. E.; Tucker, J. H. R. Organometallics 2004, 23, 946.

(11) Beer, P. B.; Graydon, A. R.; Johnson, A. O. M.; Smith, D. K. Inorg. Chem., 1997, $36,2112$.

(12) Sillen, L. G.; Warnquist, B. Ark. Kemi. 1968, 31, 315; Sillen, L. G.; Warnquist, B. Ark. Kemi. 1968, 31, 377.

(13) Havel, J. Haltafalspefo program, Mazaryle University, Brno, Maravia, Czech Republic.

(14) The titration data ( $\Delta \delta \mathrm{ppm}$ versus guest concentration) were fitted using the nonlinear curve-fitting procedure with a (1:1) binding equation using Matlab program: P. Thordarson, Chem. Soc. Rev. 2011, 40, 1305-1323.

(15) Scholz, F. Electroanalytical methods; Springer, 2002.

(16) Randles, J. E. B. Trans. Faraday Soc. 1948, 44, 327-338.

(17) Ševčik, A. Collect. Czechoslov. Chem. Commun. 1948, 13, 349-377.

(18) G.M. Sheldrick, Acta Cryst. 2015. A71, 3-8.

(19) G.M. Sheldrick, Acta Cryst. 2015 C71, 3-8. 
Graphical abstract / TOC entry

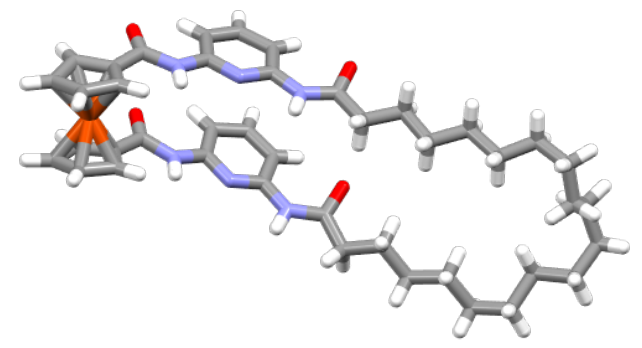

